\title{
Alarm Kebakaran Multisensor dengan Implementasi Fuzzy Dua Level
}

\author{
Hari Wahyudiono ${ }^{1}$, Ponco Siwindarto ${ }^{2}$, Bambang Siswojo ${ }^{3}$ \\ ${ }^{1}$ hariwahyudiono@sttar.ac.id, ${ }^{2}$ ponco@ub.ac.id, ${ }^{3}$ bsiswoyo@ub.ac.id \\ Program Studi Teknik Elektro, Universitas Brawijaya Malang
}

\begin{abstract}
A fire detection solution was introduced in this study, with the aim of being able to distinguish sources of fire to reduce detection errors. The system developed applies Tsukamoto's method in building two-level Fuzzy software to process fire source detection input from multisensor hardware. Tests carried out by observing the results of the reading five different sensors. Data from these sensors is processed by the Fuzzy algorithm through a computer connected to the Arduino Mega Microcontroller via serial communication. Observations were made when the system was given at least twelve different types of fire source inputs. Fuzzy performance testing is done by comparing Fuzzy 2 levels that have been developed with Fuzzy 1 levels. Then, the system is observed directly whether the system capable of distinguishing all sources of fire and fire that is not the source of the fire being tested. Fuzzy 1 level requires 234 Rule Base while Fuzzy 2 level only 54 Rule Base. The success of reading inputs reaches 80 percent, and is the best result compared to the Fuzzy 1 level alarm system that reaches 70 percent, while conventional alarm resulted 40 percent of reading accuracy.
\end{abstract}

Intisari-Sebuah solusi deteksi kebakaran diperkenalkan dalam penelitian ini, dengan tujuan dapat membedakan sumber kebakaran untuk mengurangi kesalahan deteksi. Sistem yang dikembangkan menerapkan metode Tsukamoto dalam membangun perangkat lunak Fuzzy dua level untuk memproses masukan deteksi sumber api dari perangkat keras multisensor. Pengujian dilakukan dengan mengamati hasil pembacaan lima sensor yang berbeda. Data dari sensorsensor tersebut diolah oleh algoritma Fuzzy melalui komputer yang terhubung ke Mikrokontroller Arduino Mega melalui komunikasi serial. Pengamatan dilakukan ketika sistem diberikan setidaknya sebelas jenis masukan sumber api yang berbeda. Pengujian kinerja Fuzzy dilakukan dengan membandingkan Fuzzy 2 level yang telah dikembangkan dengan Fuzzy 1 level. Kemudian, sistem diamati secara langsung apakah sistem mampu membedakan semua sumber api yang merupakan sumber kebakaran maupun yang bukan sumber kebakaran yang diujikan. Fuzzy 1 level membutuhkan 234 Rule Base sedangkan Fuzzy 2 level hanya 54 Rule Base sehingga Fuzzy 2 level lebih sederhana. Keberhasilan pembacaan deteksi kebakaran mencapai 80 persen. Hasil ini merupakan hasil paling baik dibanding dengan sistem alarm Fuzzy 1 level yang hanya mencapai 70 persen dan alarm konvensional hanya mencapai 40 persen.

\section{PENDAHULUAN}

Berdasarkan definisi yang ditetapkan oleh [1], kebakaran adalah suatu peristiwa bencana yang berasal dari api yang tidak dikehendaki yang dapat menimbulkan kerugian. Kerugian akibat kebakaran di antaranya adalah kerugian materi berupa harta benda, bangunan fisik, fasilitas sarana dan prasarana. Sedangkan kerugian yang non-materi seperti rasa takut, trauma hingga kehilangan nyawa atau cacat tubuh yang ditimbulkan akibat kebakaran [2]. Studi awal dalam penelitian ini menggunakan klasifikasi [3] bahan bakar penyebab kebakaran ke dalam empat kelas yang berbeda. Menurut data statistik [4] selama tahun 2015, telah terjadi 991.548 kasus kebakaran di dunia dan sebanyak 763.153 di antaranya adalah kebakaran gedung. Salah satu cara mencegah, mengurangi dan memadamkan kebakaran adalah dengan menyediakan sarana deteksi dan alarm kebakaran [5].

Permasalahan yang ada saat ini adalah kondisi pada pendeteksi kebakaran konvensional yang tidak bisa membedakan antara sumber kebakaran atau bukan, hal ini dapat mengakibatkan terjadinya kesalahan pembacaan sumber api, contohnya asap memasak, debu, asap rokok, dan lainlain [6]. Salah satu contoh kesalahan deteksi terjadi pada hotel di Rusia saat menggelar pertandingan piala dunia. Alarm kebakaran di hotel tempat menginap tim nasional Swedia menyala sehingga tim nasional Swedia diminta meninggalkan hotel. Kesalahan deteksi ini diakibatkan adanya penghuni hotel yang merokok sehingga memicu alarm kebakaran [7]

Dari tiga penelitian terdahulu mengenai deteksi kebakaran, salah satunya adalah deteksi kebakaran hutan dengan pendekatan sistem Fuzzy berdasarkan indeks [8]. Penelitian ini menggunakan metode Fuzzy Mamdani dengan menggunakan fungsi overlapping dan index overlapping untuk mengatasi hasil pembacaan yang overlap pada deteksi kebakaran hutan menggunakan jaringan sensor nirkabel. Pada penelitian ini tidak mempertimbangkan kesalahan pembacaan sumber api, karena penelitian untuk kawasan hutan, sehingga semua sumber api yang terdeteksi dinyatakan kebakaran.

Penelitian kedua [9], menggunakan metode teori Fuzzy dengan multisensor yaitu sensor panas, sensor asap, sensor karbon monoksida yang dikombinasikan dengan algoritma cerdas saraf tiruan untuk membuat keputusan deteksi kebakaran dan mengurangi tingkat kesalahan alarm. Dalam penelitian ini dijelaskan agar memperoleh hasil yang lebih rendah dalam kesalahan pembacaan perlu ditambahkan sensor untuk meningkatkan ketelitian dalam pembacaan.

Kata Kunci-Kebakaran; Fuzzy; Tsukamoto; Multisensor; Arduino 


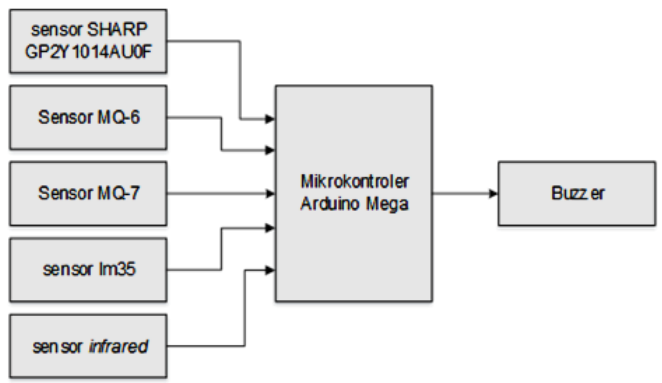

Gambar 1. Diagram Blok Sistem

Penelitian ketiga mengusulkan metode pemantauan dan perkiraan kebakaran dengan menggunakan teori Fuzzy data multisensor, berdasarkan jaringan sensor nirkabel [10]. Algoritma dan data deteksi kebakaran bersifat modular dan hierarkis. Pendekatannya tidak hanya memastikan kebenaran sistem, tetapi juga meningkatkan kecerdasan sistem pemantauan. Hasil simulasi menunjukkan bahwa metode yang diusulkan memiliki kinerja yang lebih baik daripada metode diagnosis tradisional dengan sensor tunggal. Kekurangan pada penelitian ini adalah masih dalam tahap simulasi, sehingga sistem belum diimplementasikan secara nyata.

Berdasarkan penelaahan terhadap penelitian di atas, secara umum pendeteksi dini kebakaran dengan multisensor berkinerja lebih baik daripada alarm konvensional. Hal ini terjadi karena api adalah fenomena yang komprehensif antara asap, cahaya, kenaikan suhu, radiasi dan perubahan konsentrasi gas dapat dideteksi dengan baik oleh multisensor [9]. Pembacaan sensor-sensor yang akurat dalam mendeteksi penyebab kebakaran akan lebih andal jika didukung dengan algoritma Fuzzy dalam penentuan keputusan.

Penggunaan multisensor dapat meningkatkan keefektifan sistem akan tetapi berdampak juga kepada kompleksitas logika Fuzzy, sehingga diperlukan suatu metode untuk mengatasi masalah tersebut. Untuk mengurangi kompleksitas logika Fuzzy akan dikembangkan logika Fuzzy dengan 2 level penentuan keputusan. Dengan adanya sistem pendeteksi dini kebakaran yang menggunakan multisensor berbasis metode Fuzzy 2 level diharapkan mengurangi kesalahan pembacaan pada alarm peringatan kebakaran dengan sistem Fuzzy yang sederhana.

Solusi yang diajukan dalam penelitian ini adalah sistem pendeteksi kebakaran dini menggunakan algoritma Fuzzy dua level. Pada sistem pendeteksi kebakaran yang diusulkan akan menggunakan multisensor. Sensor mendeteksi fenomena penyebab kebakaran seperti kondisi udara, kenaikan suhu, dan cahaya api. Pada tahap pertama sistem akan mendeteksi kondisi udara dengan menggunakan sensor debu/asap, sensor gas mudah terbakar, dan sensor CO. Pada level kedua penentuan alarm kebakaran mengacu pada keluaran dari Fuzzy level pertama dan ditambahkan fenomena yang lain yaitu sensor suhu dan cahaya api. Ketiga hasil pembacaan dari kondisi udara, kenaikan suhu, dan cahaya api menjadi acuan untuk algoritma Fuzzy level kedua sebagai penentu alarm kebakaran. Dengan adanya sistem pendeteksi dini kebakaran yang menggunakan multisensor berbasis metode Fuzzy 2 level, diharapkan mengurangi kesalahan pembacaan pada alarm peringatan kebakaran.

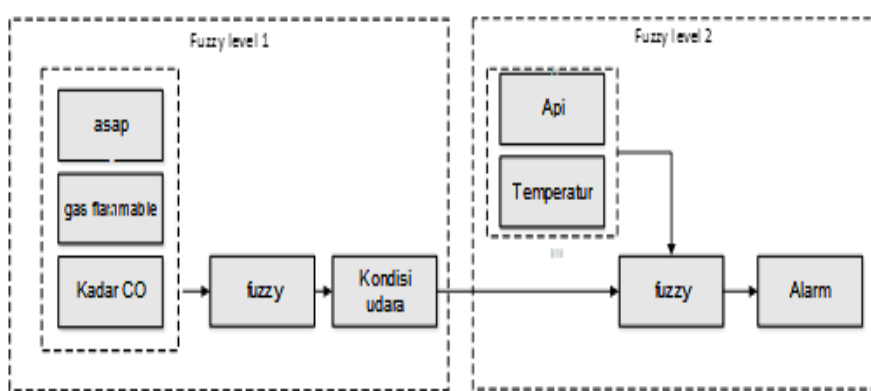

Gambar 2. Diagram Blok Fuzzy

\section{METODE PENELITIAN}

\section{A. Perancangan Perangkat Lunak}

Sistem alarm kebakaran memerlukan algoritma sebagai sistem penentu keputusan. pada penelitian ini algoritma yang digunakan adalah algoritma Fuzzy. Logika Fuzzy merupakan salah satu cabang dari ilmu komputer yang mempelajari tentang nilai kebenaran yang bernilai banyak [11]. Berbeda dengan nilai kebenaran pada logika klasik yang bernilai 0 jika salah atau 1 jika benar. Logika Fuzzy mempunyai nilai kebenaran real dalam selang $(0,1)$. Algoritma Fuzzy yang dikembangkan menggunakan komponen yang terdiri atas: Variabel Linguistik; Nilai Linguistik; dan Nilai kuantitatif dan derajat keanggotaan.

Perancangan perangkat lunak pada penelitian ini ditujukan untuk menyusun logika Fuzzy menggunakan metode Tsukamoto yang sesuai dengan kebutuhan sistem. Penelitian ini menggunakan dua level Fuzzy, sebagaimana ditampilkan pada Error! Reference source not found. tahap pertama yang dilakukan adalah perencanaan Fuzzy level satu. pada Fuzzy level satu variabel yang digunakan sebagai variabel masukan logika Fuzzy adalah kadar asap, kadar gas mudah terbakar (flammable), kadar Karbon Monoksida untuk menentukan kondisi udara.

\section{B. Perancangan Perangkat Keras}

Sistem alarm kebakaran pada penelitian ini memerlukan lima buah perangkat sensor yang digunakan untuk mendeteksi fenomena kebakaran di suatu ruangan, kemudian untuk memproses keluaran dari sensor digunakan Mikrokontroller Arduino. Keluaran yang digunakan sistem sebagai tanda kebakaran adalah Buzzer, sesuai dengan diagram blok pada Error! Reference source not found. Secara umum sensor, didefinisikan sebagai jenis transduser yang digunakan untuk mengubah besaran mekanis, magnetis, panas, sinar, dan kimia menjadi tegangan dan arus listrik [12]. Ada beberapa jenis sensor yang dapat digunakan untuk mendeteksi fenomena kebakaran, di antaranya adalah detektor asap, sensor suhu, sensor api, dan sensor gas.

Detektor Asap mempunyai beberapa jenis sesuai dengan teknik pembacaan kuantitas asap, sehingga dari beberapa teknik yang berbeda tersebut mempunyai kelebihan dan kekurangan masing-masing. Beberapa yang lazim dijumpai di antaranya adalah: Ionization Smoke Detector, Projected Beam Smoke Detector, Video Smoke Detector, dan Photoelectric Smoke Detector. Penelitian ini menggunakan sensor pendeteksi asap Photoelectric yang menggunakan cahaya untuk mendeteksi adanya gumpalan asap. Salah satu sensor asap yang menggunakan teknik tersebut adalah Optical Dust Sensor SHARP GP2Y1014AU0F. Pada sensor ini sinar 
cahaya yang berbentuk denyutan dari lampu LED atau diode pemancar inframerah diatur secara diagonal dengan phototransistor yang mendeteksi cahaya yang dipantulkan oleh debu udara di ruang pengukuran. Namun apabila terjadi kebakaran dan asapnya memasuki ruang detektor maka cahayanya akan berbelok atau terhalang sehingga mengaktifkan sinyal alarm [13]. Menurut datasheet sensor tersebut [14], sensor ini mudah mendeteksi partikel yang sangat halus seperti asap rokok. Selain itu, bisa membedakan asap dari debu rumah dengan pola pulsa tegangan output.

Sensor suhu adalah sensor yang digunakan untuk mendeteksi gejala perubahan suhu pada suatu dimensi benda atau dimensi ruang tertentu. Contoh : Bimetal, Termistor, Termokopel, RTD, dan Sensor Suhu IC. Dari lima jenis sensor suhu tersebut, sensor suhu IC LM35 menjadi pilihan utama karena memiliki presisi yang lebih tinggi dan lebih luas rentang kerja liniernya. Tegangan keluaran LM35 linier suhu Celsius proporsional, pada suhu biasa, itu dapat memberikan \pm $1 / 4{ }^{\circ} \mathrm{C}$ presisi umum suhu kamar tanpa perlu kalibrasi tambahan. Ujian menggunakan sensor suhu tipe LM35 dengan plastik pengemasan [15].

Sensor Api merupakan alat optik yang digunakan untuk mendeteksi nyala api dengan menggunakan sensor optik untuk mendeteksinya. Sensor api digunakan untuk mendeteksi keberadaan api, bukan suhu panas. Api akan bisa dideteksi oleh keberadaan spektrum cahaya inframerah ataupun ultraviolet. Detektor inframerah bekerja pada pita spectral inframerah. Gas panas akan mengeluarkan sebuah pola spectral spesifik di daerah inframerah, di mana ini akan dibaca oleh sensor inframerah yang dapat mendeteksi api dengan panjang gelombang cahaya $760 \mathrm{~nm} \sim 1100 \mathrm{~nm}$. Sensor ini dapat secara khusus mendeteksi spektrum api. Sensor dapat mendeteksi di area kerja sudut pantau 60 derajat. Suhu pengoperasian sensor adalah -25 derajat Celsius hingga 85 derajat Celsius, harus dicatat bahwa jarak pantauan dari nyala api tidak boleh terlalu dekat untuk menghindari kerusakan.

Sensor gas adalah pengindra yang terbuat dari bahan logam yang sensitif terhadap gas tertentu. sensor gas mendeteksi konsentrasi jenis gas tertentu sesuai dengan bahan dari sensor yang digunakan [16]. Sensor semikonduktor adalah sejumlah komponen elektronik yang menggunakan sifat-sifat materi semikonduktor, di antaranya Silikon, Germanium, dan Gallium Arsenide. Elemen sensor yang digunakan pada sensor gas semikonduktor adalah material Timah oksida ( $\mathrm{SnO} 2)$. Sensor gas memiliki bobot yang ringan, kecil, sudah tersedia luas dan memiliki sensitivitas tinggi. Mekanisme utama untuk reaksi gas dengan metal oksida terjadi pada suhu tinggi yaitu $200^{\circ} \mathrm{C}-600^{\circ} \mathrm{C}$ [17]. Pada penelitian ini menggunakan dua sensor gas semikonduktor, yaitu sensor MQ-6 dan MQ-7. sensor MQ-6 digunakan untuk mendeteksi gas mudah terbakar, sensor ini berbahan dasar sensitif berupa $\mathrm{SnO} 2$ yang memiliki konduktivitas lebih rendah di udara bersih.

\section{HASIL DAN PEMBAHASAN}

\section{A. Pengujian Sistem}

Pengujian dilakukan dengan mengamati hasil pembacaan Sensor Asap, Sensor Gas Karbon Monoksida, Sensor Gas Flammable, Sensor Suhu, dan Sensor Cahaya Api yang telah diolah oleh algoritma Fuzzy melalui komputer yang terhubung
Tabel 1. Hasil Pengujian Sensor Suhu LM35

\begin{tabular}{|c|c|c|c|}
\hline \multirow[b]{2}{*}{ No. } & \multicolumn{2}{|c|}{ Pembacaan Suhu } & \multirow[b]{2}{*}{$\begin{array}{c}\text { Keluaran LM35 } \\
\text { (v) }\end{array}$} \\
\hline & $\begin{array}{c}\text { Termometer } \\
\left({ }^{0} \mathrm{C}\right)\end{array}$ & $\begin{array}{c}\text { LM35 } \\
\left({ }^{0} \mathrm{C}\right)\end{array}$ & \\
\hline 1 & 28 & 28,23 & 0,283 \\
\hline 2 & 33 & 32,97 & 0,329 \\
\hline 3 & 35 & 35,29 & 0,353 \\
\hline 4 & 38 & 38,03 & 0,382 \\
\hline 5 & 40 & 40,00 & 0,4 \\
\hline 6 & 43 & 43,13 & 0,431 \\
\hline 7 & 46 & 46,27 & 0,462 \\
\hline 8 & 50 & 50,19 & 0,501 \\
\hline 9 & 54 & 54,18 & 0,541 \\
\hline 10 & 55 & 55,17 & 0,552 \\
\hline 11 & 56 & 56,17 & 0,562 \\
\hline 12 & 60 & 60,56 & 0,606 \\
\hline 13 & 63 & 63,36 & 0,634 \\
\hline 14 & 66 & 66,16 & 0,662 \\
\hline 15 & 70 & 68,96 & 0,690 \\
\hline 16 & 72 & 71,77 & 0,718 \\
\hline 17 & 74 & 74,57 & 0,746 \\
\hline 18 & 77 & 77,37 & 0,774 \\
\hline 19 & 80 & 80,17 & 0,802 \\
\hline 20 & 82 & 82,98 & 0,830 \\
\hline 21 & 85 & 85,78 & 0,858 \\
\hline 22 & 88 & 88,58 & 0,886 \\
\hline 23 & 91 & 91,38 & 0,914 \\
\hline 24 & 94 & 94,19 & 0,942 \\
\hline 25 & 96 & 96,99 & 0,970 \\
\hline 25 & 100 & 99,79 & 0,998 \\
\hline
\end{tabular}

Tabel 2. Hasil Pengujian Sensor Asap

\begin{tabular}{|c|l|c|}
\hline No. & \multicolumn{1}{|c|}{ Sumber Asap } & Output \\
\hline 1 & Lilin & 350 \\
\hline 2 & Obat Nyamuk & 378 \\
\hline 3 & Kompor & 523 \\
\hline 4 & Rokok & 670 \\
\hline 5 & Vapour & 709 \\
\hline 6 & Kertas & 729 \\
\hline 7 & Karpet & 756 \\
\hline 8 & Kayu & 797 \\
\hline
\end{tabular}

ke Mikrokontroller dengan komunikasi serial. Sistem diujikan pada ruangan khusus dengan ukuran $3 \mathrm{~m}$ x $3 \mathrm{~m}$ X 2,5m.

Pengamatan dilakukan ketika sistem diberikan masukan berupa kertas terbakar, kayu terbakar, karpet terbakar, obat nyamuk bakar, setrika, solder, lilin, rokok, kompor (memasak), kompor (terbakar), hairdryer, vapour. Pengujian kinerja Fuzzy dilakukan dengan membandingkan Fuzzy 2 level yang telah dikembangkan dengan Fuzzy 1 level saja, kemudian sistem diamati secara langsung apakah sistem mampu membedakan semua sumber kebakaran maupun api yang bukan sumber kebakaran yang diujikan pada tempat percobaan.

\section{1) Pengujian Sensor Suhu LM35:}

Pengujian sensor suhu LM35 bertujuan untuk mengetahui tingkat akurasi dan eror dari data hasil pengukuran sensor suhu. Pengamatan suhu dengan sensor akan dikirim pada serial monitor Arduino. hasil pengujian data disajikan pada Tabel 1. Dari Tabel 1 dapat diketahui bahwa sensor dapat membaca suhu dengan baik dan memiliki eror rata-rata $0,35 \%$, sehingga sensor dapat digunakan dalam penelitian.

2) Pengujian Sensor Asap:

Pengujian sensor asap Sharp GP2Y1014AU0F bertujuan untuk mengetahui pembacaan dari data hasil pengukuran sensor asap. Pengamatan kadar asap direpresentasikan 
Tabel 3. Hasil Pengujian Sensor Gas Monoksida

\begin{tabular}{|l|l|c|c|c|}
\hline No. & Sumber & ADC & $\begin{array}{c}\text { Hasil } \\
\text { pengukuran sensor } \\
(\mathrm{ppm})\end{array}$ & $\begin{array}{c}\text { Hasil } \\
\text { pengukuran } \\
\text { CO meter } \\
(\mathrm{ppm})\end{array}$ \\
\hline 1 & Lilin & 267 & 320 & 330 \\
\hline 2 & Rokok & 310 & 372 & 375 \\
\hline 3 & Kompor & 280 & 336 & 318 \\
\hline 4 & Vapour & 349 & 418 & 425 \\
\hline 5 & Obat Nyamuk & 340 & 408 & 420 \\
\hline 6 & Kertas & 519 & 662 & 653 \\
\hline 7 & Karpet & 547 & 656 & 660 \\
\hline 8 & Kayu & 496 & 595 & 610 \\
\hline
\end{tabular}

Tabel 4. Hasil Pengujian Sensor Gas Flammable

\begin{tabular}{|l|c|c|c|c|}
\hline No. & $\begin{array}{c}\text { Waktu } \\
\text { (menit) }\end{array}$ & ADC & $\begin{array}{c}\text { Hasil } \\
\text { Pengukuran } \\
\text { Sensor } \\
(\mathrm{ppm})\end{array}$ & $\begin{array}{c}\text { Hasil Pengukuran } \\
\text { alat ukur } \\
\text { (ppm) }\end{array}$ \\
\hline 1 & 1 & 10 & 210 & 200 \\
\hline 2 & 2 & 72 & 287 & 298 \\
\hline 3 & 3 & 136 & 354 & 360 \\
\hline 4 & 4 & 199 & 429 & 432 \\
\hline 5 & 5 & 257 & 493 & 505 \\
\hline 6 & 6 & 310 & 559 & 571 \\
\hline 7 & 7 & 377 & 614 & 600 \\
\hline 8 & 8 & 498 & 678 & 661 \\
\hline 9 & 9 & 560 & 750 & 759 \\
\hline 10 & 10 & 570 & 826 & 797 \\
\hline
\end{tabular}

Tabel 5. Hasil Pengujian Sensor Cahaya Api

\begin{tabular}{|c|c|c|}
\hline No. & $\begin{array}{c}\text { Jarak api } \\
(\mathrm{cm})\end{array}$ & ADC \\
\hline 1 & 10 & 38 \\
\hline 2 & 20 & 57 \\
\hline 3 & 30 & 79 \\
\hline 4 & 40 & 99 \\
\hline 5 & 50 & 112 \\
\hline 6 & 60 & 137 \\
\hline 7 & 70 & 156 \\
\hline 8 & 80 & 178 \\
\hline
\end{tabular}

melalui pembacaan ADC kemudian dikirim pada serial monitor Arduino. Hasil pengujian data disajikan pada Error! Reference source not found.

Pengujian sensor Karbon Monoksida MQ-7 bertujuan untuk mengetahui pembacaan dari data hasil pengukuran sensor gas monoksida. Pengamatan kadar gas direpresentasikan melalui pembacaan ADC kemudian dikirim pada serial monitor Arduino dan dibandingkan dengan Carbon Monoxide Meter. hasil pengujian data disajikan pada Tabel 3.

\section{3) Pengujian Sensor Gas Flammable:}

Pengujian sensor gas flammable MQ-6 bertujuan untuk mengetahui pembacaan dari data hasil pengukuran sensor suhu. Pengamatan kadar gas direpresentasikan melalui pembacaan ADC kemudian dikirim pada serial monitor Arduino dan dibandingkan dengan alat ukur Combustible Gas Detector A8800L. Hasil pengujian data disajikan pada Tabel 4.

\section{4) Pengujian Sensor Gas Flammable:}

Pengujian sensor gas flammable MQ-6 bertujuan untuk mengetahui pembacaan dari data hasil pengukuran sensor suhu. Pengamatan kadar gas direpresentasikan melalui pembacaan ADC kemudian dikirim pada serial monitor
Tabel 6. Hasil Pengujian Kinerja Sistem dengan Fuzzy Level Pertama

\begin{tabular}{|l|c|c|c|c|c|}
\hline \multirow{2}{*}{ No. } & \multirow{2}{*}{ Sumber } & $\begin{array}{c}\text { Mq- } \\
6\end{array}$ & $\begin{array}{c}\text { Mq- } \\
7\end{array}$ & $\begin{array}{c}\text { SHARP } \\
\text { GP2Y1014AU0F }\end{array}$ & $\begin{array}{c}\text { Kondisi } \\
\text { Udara }\end{array}$ \\
\cline { 3 - 6 } 1 & Setrika & 250 & 13 & 350 & 15,46 \\
\hline 2 & Solder & 260 & 11 & 367 & 14,46 \\
\hline 3 & Hairdryer & 250 & 10 & 356 & 13,97 \\
\hline 4 & Vapour & 250 & 15 & 720 & 13,95 \\
\hline 5 & Lilin & 265 & 20 & 360 & 14,48 \\
\hline 6 & Rokok & 300 & 25 & 670 & 14,50 \\
\hline 7 & $\begin{array}{c}\text { Obat } \\
\text { Nyamuk } \\
\text { Bakar }\end{array}$ & 320 & 50 & 380 & 17,00 \\
\hline 8 & $\begin{array}{c}\text { Kompor } \\
\text { Memasak })\end{array}$ & 300 & 75 & 525 & 18,00 \\
\hline 9 & $\begin{array}{c}\text { Kertas } \\
\text { Terbakar }\end{array}$ & 525 & 30 & 739 & 17,98 \\
\hline 10 & $\begin{array}{c}\text { Kayu } \\
\text { Terbakar }\end{array}$ & 510 & 40 & 802 & 18,00 \\
\hline 11 & $\begin{array}{c}\text { Karpet } \\
\text { Terbakar }\end{array}$ & 550 & 35 & 780 & 19,11 \\
\hline
\end{tabular}

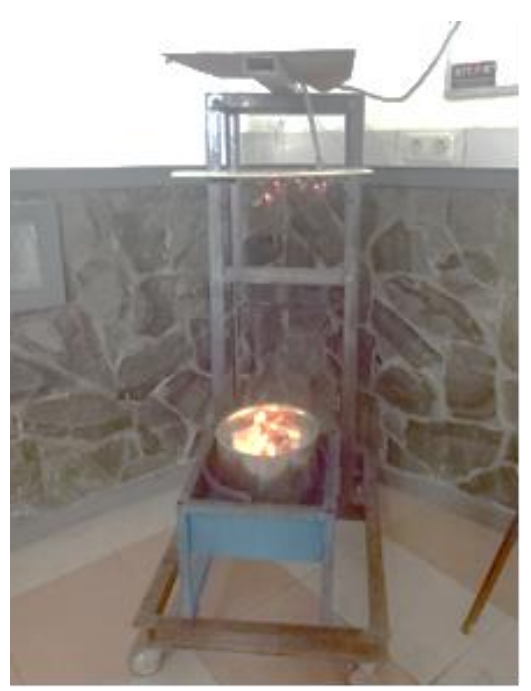

Gambar 3. Implementasi Sistem

Arduino dan dibandingkan dengan alat ukur Combustible Gas Detector A8800L. Hasil pengujian data disajikan pada Tabel 4.

\section{5) Pengujian Sensor Cahaya Api:}

Pengujian sensor cahaya api menggunakan infrared bertujuan untuk mengetahui pembacaan dari data hasil pengukuran sensor cahaya api tersebut. Pengamatan besarnya cahaya api direpresentasikan melalui pembacaan ADC kemudian dikirim pada serial monitor Arduino. Hasil pengujian data disajikan pada Tabel 5.

\section{B. Implementasi dan Pengujian Sistem}

Tahap implementasi sistem dilakukan dengan merangkai semua komponen sensor yang dihubungkan sedemikian rupa untuk menjadi masukan untuk Mikrokontroller Arduino Mega. Setelah semua perangkat keras terpasang, kemudian dilakukan perancangan Fuzzy dua level yang selanjutnya diprogram ke dalam Arduino Mega. Hasil Implementasi sistem disajikan pada Error! Reference source not found.

Sistem diujikan pada ruangan khusus dengan ukuran $3 \mathrm{~m} \mathrm{x}$ $3 \mathrm{~m} \times 2,5 \mathrm{~m}$. Pengamatan dilakukan ketika sistem diberikan masukan berupa kertas terbakar, kayu terbakar, karpet terbakar, obat nyamuk bakar, setrika, solder, lilin, rokok, kompor (memasak), kompor (terbakar), hairdryer, dan vapour. Pengujian kinerja Fuzzy dilakukan dengan membandingkan 
Tabel 7. Hasil Pengujian Kinerja Sistem dengan Fuzzy Level Keduaa

\begin{tabular}{|c|l|c|c|c|c|}
\hline \multirow{2}{*}{ No. } & \multirow{2}{*}{ Sumber } & $\begin{array}{c}\text { Kondisi } \\
\text { udara }\end{array}$ & LM35 & Infrared & Alarm \\
\cline { 3 - 6 } & & 15,46 & 34 & 172 & 65,74 \\
\hline 2 & Setrika & 14,46 & 39 & 178 & 58,80 \\
\hline 3 & Solder & 13,97 & 40 & 171 & 55,27 \\
\hline 4 & Vairdryer & 13,95 & 34 & 170 & 53,43 \\
\hline 5 & Lilin & 14,48 & 35 & 110 & 51,94 \\
\hline 6 & Rokok & 14,50 & 35 & 169 & 50,87 \\
\hline 7 & $\begin{array}{l}\text { Obat Nyamuk } \\
\text { Bakar }\end{array}$ & 17,00 & 36 & 157 & 79,48 \\
\hline 8 & $\begin{array}{l}\text { Kompor } \\
\text { Memasak) }\end{array}$ & 18,00 & 60 & 40 & 84,40 \\
\hline 9 & $\begin{array}{l}\text { Kertas } \\
\text { Terbakar }\end{array}$ & 17,98 & 75 & 38 & 84,76 \\
\hline 10 & $\begin{array}{l}\text { Kayu } \\
\text { Terbakar }\end{array}$ & 18,00 & 78 & 40 & 84,24 \\
\hline 11 & $\begin{array}{l}\text { Karpet } \\
\text { Terbakar }\end{array}$ & 19,11 & 75 & 32 & 84,63 \\
\hline
\end{tabular}

Tabel 6. Hasil Pengujian Kinerja Sistem Keseluruhan

\begin{tabular}{|l|l|l|l|l|}
\hline No. & Sumber & Konvensional & Fuzzy 1 level & Fuzzy 2 level \\
\hline 1 & Setrika & Alarm mati & Alarm mati & Alarm mati \\
\hline 2 & Solder & $\begin{array}{l}\text { Alarm } \\
\text { menyala }\end{array}$ & Alarm mati & Alarm mati \\
\hline 3 & Hairdryer & Alarm mati & Alarm mati & Alarm mati \\
\hline 4 & Vapour & $\begin{array}{l}\text { Alarm } \\
\text { menyala }\end{array}$ & Alarm mati & Alarm mati \\
\hline 5 & Lilin & $\begin{array}{l}\text { Alarm } \\
\text { menyala }\end{array}$ & $\begin{array}{l}\text { Alarm } \\
\text { menyala }\end{array}$ & Alarm mati \\
\hline 6 & Rokok & $\begin{array}{l}\text { Alarm } \\
\text { menyala }\end{array}$ & Alarm mati & Alarm mati \\
\hline 7 & $\begin{array}{l}\text { Obat } \\
\text { Nyamuk } \\
\text { Bakar }\end{array}$ & $\begin{array}{l}\text { Alarm } \\
\text { menyala }\end{array}$ & $\begin{array}{l}\text { Alarm } \\
\text { menyala }\end{array}$ & $\begin{array}{l}\text { Alarm } \\
\text { menyala }\end{array}$ \\
\hline 8 & $\begin{array}{l}\text { Kompor } \\
\text { (Memasak })\end{array}$ & $\begin{array}{l}\text { Alarm } \\
\text { menyala }\end{array}$ & $\begin{array}{l}\text { Alarm } \\
\text { menyala }\end{array}$ & $\begin{array}{l}\text { Alarm } \\
\text { menyala }\end{array}$ \\
\hline 9 & $\begin{array}{l}\text { Kertas } \\
\text { Terbakar }\end{array}$ & $\begin{array}{l}\text { Alarm } \\
\text { menyala }\end{array}$ & $\begin{array}{l}\text { Alarm } \\
\text { menyala }\end{array}$ & $\begin{array}{l}\text { Alarm } \\
\text { menyala }\end{array}$ \\
\hline 10 & $\begin{array}{l}\text { Kayu } \\
\text { Terbakar }\end{array}$ & $\begin{array}{l}\text { Alarm } \\
\text { menyala }\end{array}$ & $\begin{array}{l}\text { Alarm } \\
\text { menyala }\end{array}$ & $\begin{array}{l}\text { Alarm } \\
\text { menyala }\end{array}$ \\
\hline 11 & $\begin{array}{l}\text { Karpet } \\
\text { Terbakar }\end{array}$ & $\begin{array}{l}\text { Alarm } \\
\text { menyala } \\
\text { menyala }\end{array}$ & $\begin{array}{l}\text { Alarm } \\
\text { menyala }\end{array}$ \\
\hline
\end{tabular}

Fuzzy 2 level yang telah dikembangkan dengan Fuzzy 1 level saja, kemudian sistem diamati secara langsung apakah sistem mampu membedakan semua sumber kebakaran maupun api yang bukan sumber kebakaran yang diujikan pada tempat percobaan.

\section{Analisis Hasil Pengujian}

Pengujian implementasi Fuzzy dua level dapat dilihat dengan cara memberikan input sesuai dengan perencanaan, kemudian dilihat dan dianalisis hasil dari sistem tersebut. Hasil implementasi Fuzzy dua level pada level pertama dapat dilihat pada Tabel. Hasil implementasi Fuzzy level kedua disajikan pada Error! Reference source not found.. Kinerja sistem keseluruhan pada penelitian ini dapat dilihat dari besarnya persentase eror pengenalan pembacaan sumber kebakaran atau sumber api normal yang dibandingkan dengan hasil pembacaan alarm konvensional dan Fuzzy satu level. Hasil pengujian kinerja sistem Alarm dapat dilihat pada Tabel 6.
Dari Tabel 8 dapat diketahui bahwa alarm konvensional mempunyai kesalahan yang sangat besar dalam mengenali sumber kebakaran dari 10 sumber yang diujicobakan hanya terdapat $40 \%$ pembacaan tepat, hal ini dikarenakan setiap alarm kebakaran konvensional mendeteksi asap langsung akan menyala. Pada alarm yang menggunakan Fuzzy 1 level mempunyai keakuratan sebesar $70 \%$ hal ini disebabkan karena penyusunan Rule Base yang sangat banyak yaitu 234 aturan sehingga mempengaruhi kinerja dari Fuzzy yang dibuat.

Pada alarm Fuzzy dua level mempunyai keakuratan sebesar $80 \%$ hal ini disebabkan karena pada saat mendeteksi objek obat nyamuk bakar dan kompor saat memasakan mempunyai output sistem mendekati dengan kebakaran sehingga dikenali sebagai kebakaran.

\section{KESIMPULAN DAN SARAN}

Penelitian ini menghasilkan kesimpulan bahwa dengan menggunakan lima buah sensor lebih representatif dalam pembacaan sumber kebakaran dibandingkan alarm konvensional. Sensor MQ-7, sensor MQ-6, Sharp GP2Y1014AU0F, Sensor Cahaya Api menggunakan sensor Infrared, dan Sensor Suhu menggunakan sensor LM35 yang digunakan berhasil untuk mengurangi tingkat kesalahan pembacaan dan alarm kebakaran palsu.

Fuzzy dua level pada penelitian ini dapat mengurangi kompleksitas algoritma Fuzzy dibandingkan dengan Fuzzy 1 level. Hal ini dapat dilihat dari banyaknya Rule Base dari masing-masing Fuzzy. Fuzzy 1 level membutuhkan 234 Rule Base sedangkan Fuzzy 2 level hanya 54 Rule Base. Algoritma Fuzzy dua level pada alarm kebakaran dengan multisensor mempunyai algoritma Fuzzy yang sederhana namun tetap mampu mengurangi kesalahan pembacaan alarm kebakaran palsu. Keberhasilan pembacaan mencapai $80 \%$ hasil ini merupakan hasil paling baik dibanding dengan sistem alarm Fuzzy 1 level yang hanya mencapai $70 \%$ dan alarm konvensional hanya mencapai 40

Dapat digunakan sensor yang mempunyai cakupan lebih luas untuk pengembangan selanjutnya. Tidak hanya pada aspek perangkat keras, Fuzzy 2 level dapat dilakukan penelitian lain dengan skema bervariasi. Terakhir, sistem alarm dapat dikembangkan menggunakan Fuzzy dengan inferensi yang lain misalnya metode Sugeno atau Mamdani.

\section{DAFTAR PUSTAKA}

[1] National Fire Protection Association, "NFPA - Smoke alarms," National Fire Protection Association, 2000. [Daring]. Tersedia pada: https://www.nfpa.org/PublicEducation/Staying-safe/Safety-equipment/Smoke-alarms. [Diakses: 20-Jul-2018].

[2] Dewan Keselamatan dan Kesehatan Kerja Nasional, Pedoman Praktis Manajemen Kebakaran. Jakarta: Dewan Keselamatan dan Kesehatan Kerja Nasional (D3KN), 2000.

[3] N. N. Brushlinsky, M. Ahrens, S. V Sokolov, dan W. Peter, "World Fire Statistics | CTIF - International Association of Fire Services for Safer Citizens through Skilled Firefighters," 22, 2017. 
[4] National Fire Protection Association, "NFPA Report First Revision No.1-NFPA 921-2015," National Fire Protection Association, 2015.

[5] Kementerian Tenaga Kerja Republik Indonesia, Keputusan Menteri Tenaga Kerja Republik Indonesia No.Kep.186/Men/1999 Tentang Unit Penanggulangan Kebakaran di Tempat Kerja. Jakarta: Kementerian Tenaga Kerja Republik Indonesia, 1999.

[6] County Durham and Darlington Fire and Rescue Service, "False Alarm Incident Statistics," 2019. [Daring]. Tersedia pada: https://www.ddfire.gov.uk/false-alarmincident-statistics. [Diakses: 13-Jun-2018].

[7] R. Francisko, "Piala Dunia 2018: Skuat Swedia Dipaksa Tinggalkan Hotel?," Indosport Bola Internasional, 2018. [Daring]. Tersedia pada: https://www.indosport.com/sepakbola/20180709/pialadunia-2018-skuat-swedia-dipaksa-tinggalkan-hotel. [Diakses: 13-Jun-2018].

[8] S. Garcia-Jimenez, A. Jurio, M. Pagola, L. De Miguel, E. Barrenechea, dan H. Bustince, "Forest fire detection: A fuzzy system approach based on overlap indices," Applied Soft Computing Journal, vol. 52, hal. 834-842, 2017.

[9] D. Zhang, X. Ma, dan A. Chang, "Design of Gas fireextinguishing control panel based on multi-sensor information fusion," in 2011 International Conference on Multimedia Technology, ICMT 2011, 2011, hal. 6299-6302.

[10] X. Hu dan X. Wang, "Application of fuzzy data fusion in multi-sensor fire monitoring," in Proceedings - 2012 International Symposium on Instrumentation and Measurement, Sensor Network and Automation, IMSNA
2012, 2012, vol. 1, hal. 157-159.

[11] S. Kusumadewi dan H. Purnomo, Aplikasi Logika Fuzzy untuk Pendukung Keputusan. Yogyakarta: Graha Ilmu, 2010.

[12] A. Suharjono, L. N. Rahayu, dan R. Afwah, "Aplikasi Sensor Flow Water Untuk Mengukur Penggunaan Air Pelanggan Secara Digital Serta Pengiriman Data Secara Otomatis," Teknik Elektro, Politeknik negeri Semarang, vol. 13, no. 1, hal. 7-12, 2015.

[13] U. Z. Jovanovic, I. D. Jovanovic, A. Z. Petrusic, Z. M. Petrusic, dan D. D. Mancic, "Low-cost wireless dust monitoring system," in 2013 11th International Conference on Telecommunications in Modern Satellite, Cable and Broadcasting Services, TELSIKS 2013, 2013, vol. 2, hal. 635-638.

[14] Sharp Corporation, "Sharp Compact Optical Dust Sensor - GP2Y1010AU0F Datasheet." Sharp Corporation, 2006.

[15] C. Liu, W. Ren, B. Zhang, dan C. Lv, "The application of soil temperature measurement by LM35 temperature sensors," in Proceedings of 2011 International Conference on Electronic and Mechanical Engineering and Information Technology, EMEIT 2011, 2011, vol. 4, hal. 1825-1828.

[16] T. A. Jones dan P. T. Walsh, "Flammable gas detection The role of the platinum metals," Platinum Metals Review, vol. 32, no. 2, hal. 50-60, 1988.

[17] A. Oktorizal, "Studi Sensor Gas Berbasis Surface Acoustic Wave untuk Penerapan pada Sistem Identifikasi Gas," Padang, 2010. 